A. Goroshko, T. Derkach,T. Dmytrenko

Poltava National Technical Yuri Kondratyuk University, Poltava,Ukraine

\title{
PROGRAM DEVELOPMENT FOR MOBILE CONTROL OF FUNCTIONAL HUMAN CONDITION ON ANDROID PLATFORM
}

\begin{abstract}
The subject of the study is the question of expediency and relevance of the development of software applications for mobile control of the human functional state on the Android platform. This platform occupies a major market share and development forecasts are quite optimistic, therefore, writing applications that are based on this system are relevant and in demand. An analysis of the current direction of mobile and wireless technologies for information support in the field of health care. The presented problems and contradictions are connected, in particular, with the insufficient level of participation of professional doctors in the development of applications, low computer literacy of the population and the high cost of such technologies. The analysis of medical mobile concepts and technologies covering new areas, including the emergence of more complex programs for the analysis of diagnostic information, the attraction of new types of portable devices is carried out. The purpose of the study is to create a mobile application to measure human fatigue on the basis of the KCHZM. As a result of the study, the software code was developed and the program was tested on several mobile devices. Conclusions The proposed complex for the determination of visual fatigue was tested and recommended for industrial implementation. The claimed technical solution can be used in the field of safety of life, industrial sanitation, in particular in the system of determining the level of fatigue of programmers, operators of personal computers, students, athletes.
\end{abstract}

Keywords: mobile devices, mobile applications, Android operating system, software code.

\section{Urgency of work}

Mobile devices have become an integral part of our everyday life, both at work and at home. The use of mobile and wireless technologies in the field of healthcare has recently become an increasingly important trend in the development of mobile medicine. As you know, the smartphone is not so complex, it is a few blocks: operational and built-in memory, a processor, necessary for various computing, data warehouse.It is also responsible for the connection of the radio module, in turn, formed from the transmitter and receiver. From a mobile phone, smartphones differ mainly in the presence of the operating system. From the work of the platform and its version depends on the main functional of the device and its capabilities. Smartphones, like other multimedia devices, can be different sets and their work can be based on different systems. The study examines the Android platform from a well-known Google company.

Analysis of recent research and publications. At the moment, Android is leading the market for operating systems and its share is $48.8 \%$. Predictions for this platform are positive. Important aspects of the growth of dynamics were the following characteristics, such as openness of the system, the ability to make changes to the main programs, the ability to quickly and easily develop. Therefore, the choice of. AN Android app development is very relevant. Information technologies are actively implemented in various spheres of life, including health care, which leads to a fundamental change in the people life quality. Mobile healthcare is one of the promising dynamic areas of eHealth, which aims to provide mobile and wireless technologies for health information, health services and healthy lifestyles. This direction can be divided into 5 main groups:

- programs (applications) of medical orientation;

- medical information services, including emergency telephony services
- diagnostic devices for smartphones, including various devices or gadgets (chips, belts, bracelets, "smart" glasses, etc.);

mobile telemedicine, designed for remote interaction both within the medical community and for communication with the patient;

- management of medical data, co-ordination of the work process of institutions in the field of health care.

The highest activity in the field of mHealth is shown primarily by countries with high per capita income. According to a survey, $72 \%$ of physicians in Germany, Great Britain and France are actively using mobile technology in their practice [1]. The benefits of such technologies are evident: on the one hand, they are able to make health care more accessible, convenient and understandable to the patient, on the other hand, they can provide the physician with comprehensive technical and advisory support, which ultimately leads to improved quality of medical care.

Currently there are over 100,000 healthcare applications developed on Android and iOS platforms. They are intended for physicians, patients, and people caring for their health. Mobile healthcare is one of the promising, dynamic areas of eHealth, which aims to provide mobile and wireless technologies for health information, health services and healthy lifestyles. This direction can be divided into 5 main groups:

- implementation of remote monitoring of the patient's condition, control of treatment effectiveness, adherence and accuracy of patient compliance with medical prescriptions;

- calculation of individual diagnostic parameters and physiological parameters (medical calculators);

- advisory (informational) support of doctors and patients.

The use of computer technologies for disease prevention includes the use of various mobile applications for healthy lifestyles (wellness), for physical training and fitness (fitness) with the control of 
individual physiological and anthropometric indicators, the fight against harmful habits, the formulation and adjustment of diet. These programs have varying degrees of complexity and can be used by the patient either independently or in conjunction with a physician. Mobile fitness programs allow you to make individual physical training programs, taking into account the impact on certain muscle groups, the analysis of the performed or planned physical activity, etc. They are able to maintain an interest in performing regular physical exercises [1]. The most popular apps are the apps for jogging, yoga, and therapeutic exercise. Studies on the evaluation of the effectiveness of fitness applications are extremely small. Of particular importance are the applications that motivate a person to abandon bad habits, primarily from smoking. From a significant number of such programs, effectiveness has been confirmed only in a few, so their widespread use in everyday practice requires further study [2].

Medical calculators - a convenient electronic tool that allows you to automatically calculate various physiological and diagnostic parameters. Universal calculators are created for the simultaneous calculation of several parameters. The process of testing the most popular of them showed that they are characterized by almost absolute precision and meet all the basic needs of clinicians. Among the most frequently recommended include Medscape, Calculate by QxMD, MediCalc [3]. Advice programs are electronic versions of manuals and manuals optimized for use on mobile devices [4]. The most common among the experts are such programs as the Medicaid Guide, the Handbook of diseases, the Medical Group Soft, the pharmaceutical applications Microdemex, Johns Hopkins ABX Guide, Epocrates.

By the end of 2014, smartphone applications Figure 1 has been launched in all European countries, which, like the Instagram service, gives doctors the opportunity to share with each other and with students of medical schools images of clinical cases [4]. In this case, the confidentiality of information is preserved patients' faces are automatically obscured, access to medical or any other personal information about the patient is not provided.

The most promising direction is the development and implementation of various diagnostic devices that are joining smartphones. Mobile phones are becoming a kind of express labs and instrumental diagnostic devices. It is projected that the main part of the market for mHealth products will be devices ("smart" glasses, watches, bracelets, etc.) that record various health parameters and send them through a wireless connection to a doctor. Quite promising is the development of specialists from Taiwan, based on which "smart" clothes, which contains a lot of sensors, allows monitoring of the main indicators of vital activity (body temperature, ECG, pulse) remotely with the use of a smartphone as the central communication device. With new programs and devices, you can make more effective prevention and early diagnosis of diseases, improve the health care system.

Devices will become more functional and tiny. Everyone will be able to independently monitor their health. Electronic cards of patients can be combined with other applications, for example, with a reminder of a visit to a doctor or taking medicine. The future is due to the integration of mobile technologies and other areas of health informatization.

Setting objectives. The main purpose of the study is to create a mobile application to measure human fatigue on the basis of the CPCM.

\section{Material and research results}

In view of all the above arguments for expediency and relevance of mobile control of the human's functional state, we worked with the Android platform, which allowed us to write a code in Java abstracting from the core. And create a mobile application to measure human fatigue based on the CPCM. At work, we noted that this operating system has such advantages as: a framework that has a wide set of APIs for the creatures of various types of applications and enables the reuse and replacement of components offered by the platform and other applications. And also the presence of Dalvik virtual machine, which provides the launch of applications. In addition, Android tools include SQLite database, 2D and 3D graphics, Media Player, communications, exchange protocols and various libraries.

Java Development Kit is a multiplatform interactive package developed for Java developers. The kit consists of several components, such as the java compiler, standard libraries, examples and templates, as well as utilities required for work. You need to install an IDE application that helps programmers write code. This program provides a brief set of tools such as debuggers, compilers, and more. Such integrated development environments are used by seasonal developers and novices who want to create an application.

There are many IDEs on the Internet, I recommend using the free Eclipse software, due to the fact that Google provides a plug-in to integrate it with the Android SDK. When you download the executable file, you must start the installation. Android Software Development Kit consists of documentation, utilities, a wide range of tools and various examples. The SDK includes a debugger, a memory and performance profile that is needed to for detecting memory leaks and find inefficient codes, device emulators, utilities needed to communicate with devices, and create packages. After all the necessary applications and plug-ins have been installed, the program code was written. Upon completion of the program code development and testing of the program on several mobile phones, a table of basic parameters was compiled (Table 1). The results of mobile devices are shown in Fig. 1-4.

\section{Conclusions}

1. Mobile healthcare is one of the most important projects in medicine that will significantly improve the availability and quality of medical care, awareness of the community, simplify diagnostic procedures, reduce financial costs, and improve the management of the health system as a whole.

2. The active introduction of mobile technologies into day-to-day clinical practice will improve this interaction and bring it to a qualitatively new level. . 
Table 1. Mobile application parameters fixed on different models of smartphones

\begin{tabular}{|l|c|c|c|c|c|}
\hline $\begin{array}{c}\text { The name of the mobile } \\
\text { device }\end{array}$ & $\begin{array}{c}\text { Android } \\
\text { version }\end{array}$ & $\begin{array}{c}\text { Number } \\
\text { of RAM }\end{array}$ & $\begin{array}{c}\text { The size of the } \\
\text { attachment to fit }\end{array}$ & $\begin{array}{c}\text { The size of the application } \\
\text { after placement }\end{array}$ & Using RAM \\
\hline HTC Desire 820 & 6.0 .1 & 2 ГБ & $1 \mathrm{MБ}$ & $1,93 \mathrm{MБ}$ & $32 \mathrm{MБ}$ \\
\hline Huawei HONOR 8 & 8.0 .0 & 4 ББ & $1 \mathrm{MБ}$ & $8,92 \mathrm{MБ}$ & $32 \mathrm{MБ}$ \\
\hline Huawei HONOR 6 & 4.4 .2 & ЗГБ & $1 \mathrm{MБ}$ & $5,76 \mathrm{MБ}$ & $32 \mathrm{MБ}$ \\
\hline
\end{tabular}

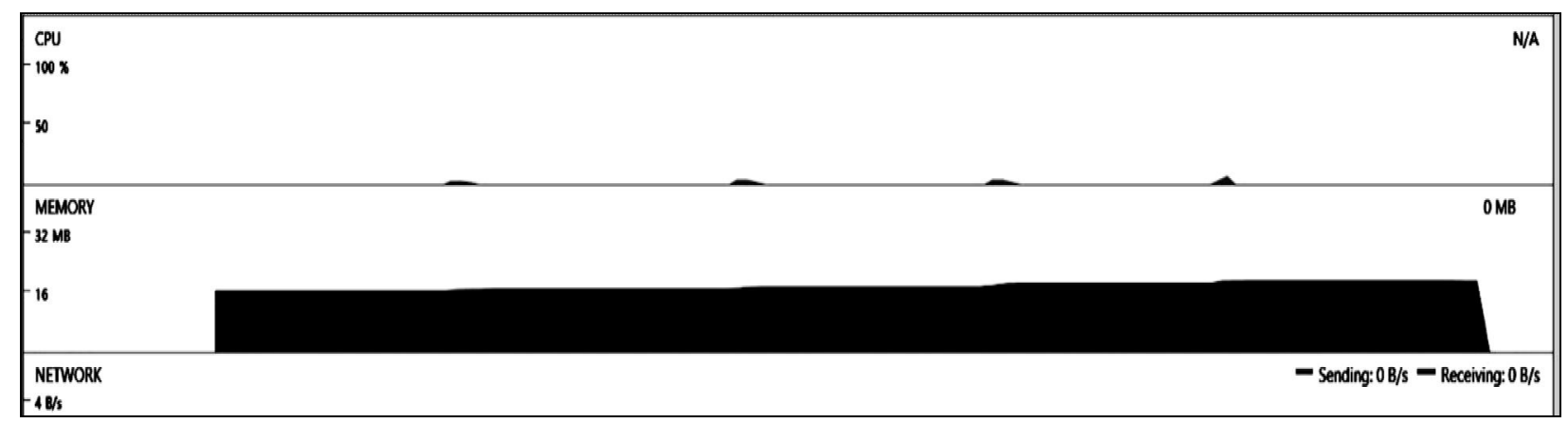

Fig. 1. Work on the HTC Desire 820

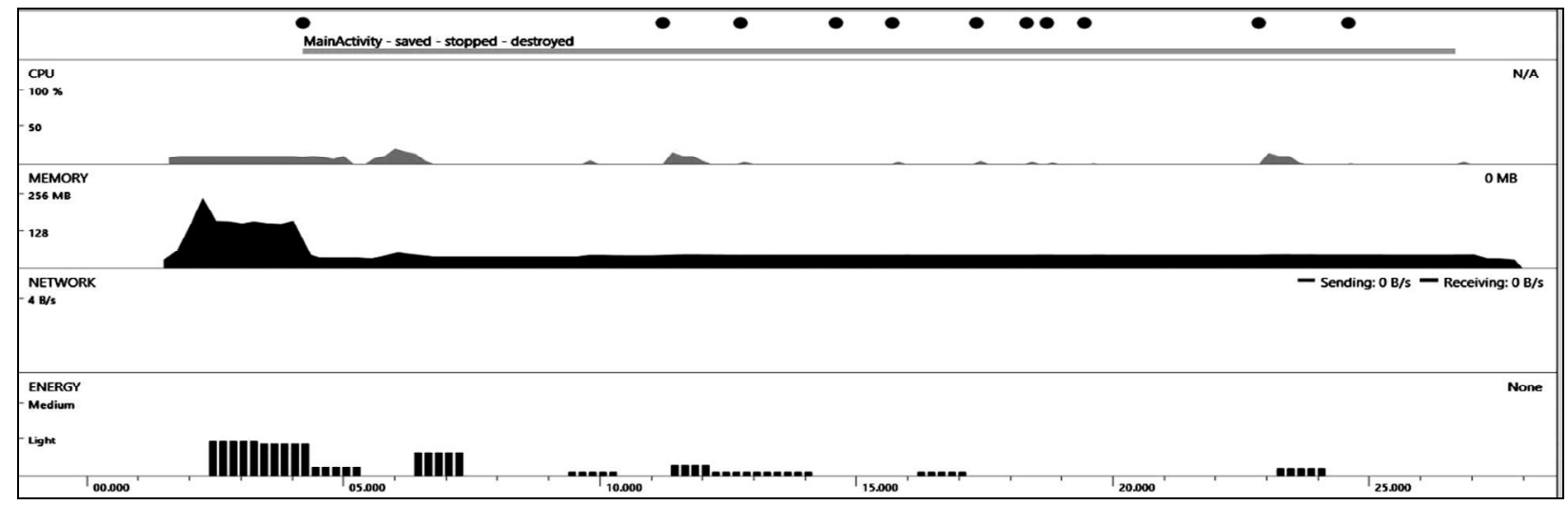

Fig. 2. The work of the application on Huawei HONOR 8

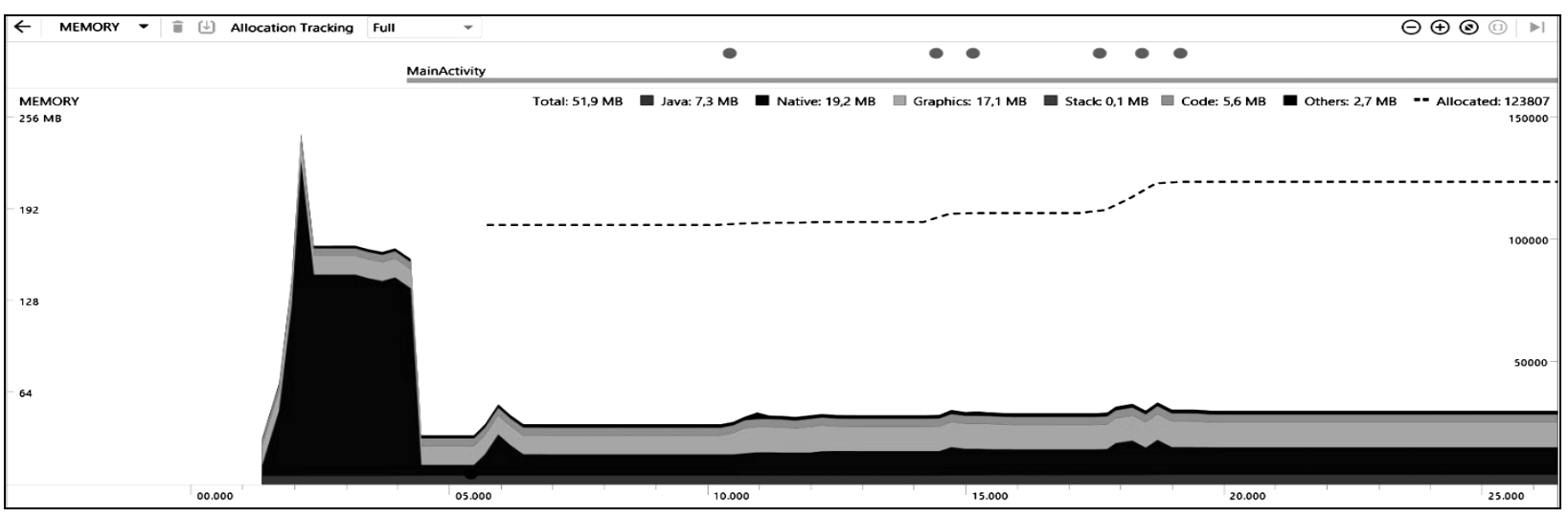

Fig. 3. The work of the application on Huawei HONOR 8

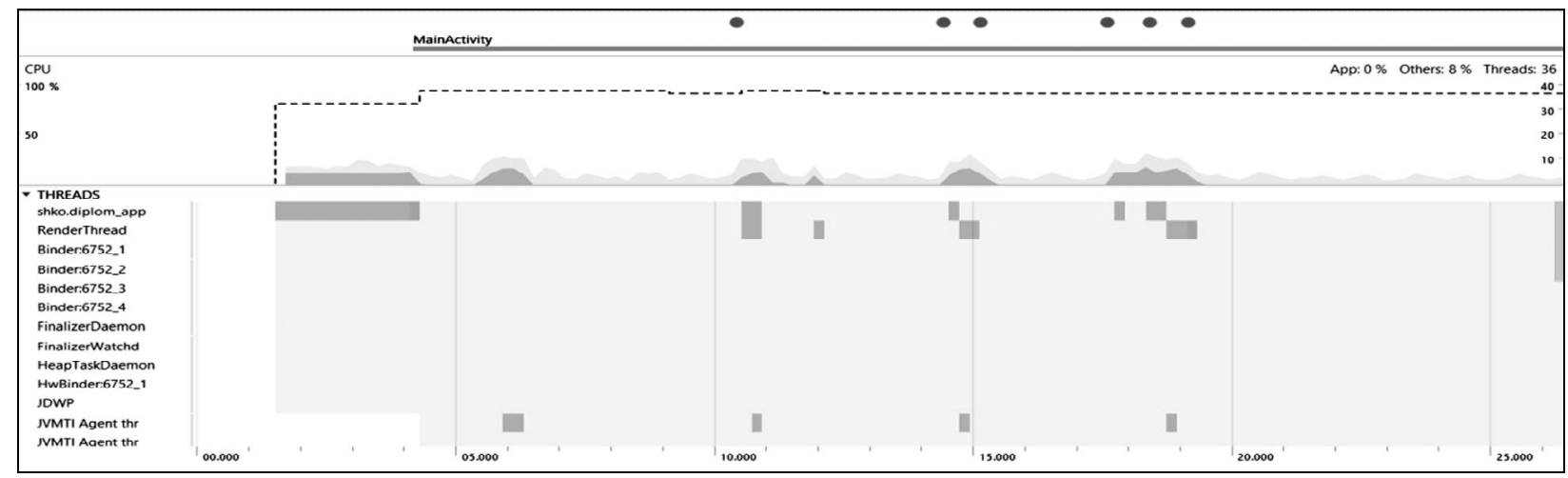

Fig. 4. Work of the processor in the exchange of data with the microcontroller 
3. The attraction of microcontroller technology with a wireless interface makes it possible to substantially simplify the component base of the electronic part of the developed complex and expand the functional of the human fatigue diagnostic tool.

4. The mobilization of smart-tools facilitates the introduction of remote monitoring and smoothness of key parameters of the diagnostic process.

5. Measurement accuracy increased by $67 \%$ compared with the previous model.
6. The proposed software makes the diagnostic procedure accessible and easy for most diagnostic operators. The proposed complex for the determination of visual fatigue was tested and recommended for industrial implementation. The stated technical solution can be used in the field of life safety, industrial sanitation, in particular in the system of determining the level of fatigue of programmers, operators of personal computers, dispensary observations on the state of view of students, students, athletes.

\section{REFERENCES}

1. Laure TAK., Lahutina N.S., Paramonov I.V. Development of algorithm for measuring human pulse frequency using a mobile phone camera. Modeling and analysis of information systems 2014; 21 (4): 91-103.

2. Shostak N.A., Muradiancz A.A. Early rheumatoid arthritis: algorithms for diagnosis and treatment. Pharmacy 2011; (11): 61-6.

3. Svarcz V.A., Hridnev V.I., Kyselov A.R., Posnenkova O.M. Clinical efficacy of dynamic outpatient monitoring technology for patients with arterial hypertension using a computer system and mobile telephony. Saratov Scientific Medical Journal 2009; 5 (3): 358-62.

4. Levin A. Android on tablets and smartphones; St.Petersburgh - Moscow, 2013. - 223 p

Рецензент: д-р техн. наук, проф. К. С. Козелкова, Державний університет телекомунікацій, Київ Received (Надійшла) 21.01.2019

Accepted for publication (Прийнята до друку) 13.03.2019

\section{Розробка програми для мобільного контролю функціонального стану людини на платформі Android}

\section{А. I. Горошко, Т. М. Деркач, Т. А. Дмитренко}

Предметом дослідження є питання доцільності та актуальності розробки програмних додатків для мобільного контролю функціонального стану людини на платформі Андроид. Дана платформа займає основну частку ринку і прогнози розвитку досить оптимістичні, отже, написання додатків, які працюють на основі даної системи є актуальними i затребуваними. Проаналізовано існуючий на даний годину напрямок мобільних і бездротових технологій для інформаційної підтримки в галузі охорони здоров'я. Наведені існуючи проблеми і протиріччя, пов' язані, зокрема, 3 недостатнім рівнем участі професійних медиків в розробці додатків, низькою комп'ютерною грамотністю населення $\mathrm{i}$ високою вартістю подібних технологій. Проведене аналіз медичних мобільних концепцій та технологій, які охоплюють нові області, включаючи появу більш складних програм для аналізу діагностичної інформації, залучення нових видів портативних пристроїв. Метою дослідження є розробка мобільного додатку для вимірювання втоми людини на основі КЧЗМ. У результаті проведеного дослідження розроблено програмний код та виконано тестування програми на декількох мобільних прибудовах. Висновки. Запропонований комплекс для визначення візуальної втоми був перевірений і рекомендований для індустріального виконання. Представлене технічне рішення може бути використано у сфері безпеки життя, індустріальної санітарії, зокрема в системі визначення рівня втоми програмістів, операторів персональних комп'ютерів, студентів, спортсменів.

Ключові слова: мобільні пристрої, мобільні додатки, операційна система Android, програмний код.

\section{Разработка программы для мобильного контроля функционального состояния человека на платформе Android}

\section{А. И. Горошко, Т. Н. Деркач, Т. А. Дмитренко}

Предметом исследования является вопрос целесообразности и актуальности разработки программных приложений для мобильного контроля функционального состояния человека на платформе Андроид. Данная платформа занимает основную долю рынка и прогнозы развития достаточно оптимистичные, следовательно, вопрос написания приложений, которые работают на основе данной системы есть актуальным и востребованным. Проанализировано существующее на данное время направление мобильных и беспроволочных технологий для информационной поддержки в отрасли здравоохранения. Приведены существующие проблемы и противоречия, связанные, в частности, с недостаточным уровнем участия профессиональных медиков в разработке приложений, низкой компьютерной грамотностью населения и высокой стоимостью подобных технологий. Проведен анализ медицинских мобильных концепций и технологий, которые охватывают новые области, включая появление более сложных программ для анализа диагностической информации, привлечения новых видов портативных устройств. Цель исследования - создание мобильного приложение для измерения усталости человека на основе КЧСМ. В результате проведенного исследования разработан программный код и выполнено тестирование программы на нескольких мобильных устройствах. Выводы. Предложенный комплекс для определения визуальной усталости был проверен и рекомендован для индустриального выполнения. Представленное техническое решение может быть использовано в сфере безопасности жизни, индустриальной санитарии, в частности в системе определения уровня усталости программистов, операторов персональных компьютеров, студентов, спортсменов.

Ключевые слова: мобильные устройства, мобильные приложения, операционная система Android, программный код. 